\title{
ROR2 wt Allele
}

National Cancer Institute

\section{Source}

National Cancer Institute. ROR2 wt Allele. NCI Thesaurus. Code C52216.

Human ROR2 wild-type allele is located within $9 q 22$ and is approximately $228 \mathrm{~kb}$ in length.

This allele, which encodes tyrosine-protein kinase transmembrane receptor ROR2

protein, may play a role in early chondrocyte formation or may be required for cartilage

and growth plate development, but an exact function has yet to be determined.

Mutations in the gene can cause brachydactyly type B and the autosomal recessive form of Robinow syndrome. 